\title{
A Retrospective Study on Wild Orphan Animals in Afyon Kocatepe University Wildlife Rescue Rehabilitation, Training, Practice and Research Center (AKUREM)
}

\author{
Emine Hesna KANDIR*, Tuğrul Çağrı GÜL \\ *Afyon Kocatepe University, Veterinary Faculty, Department of Wild Animal Diseases and Ecology, Afyonkarahisar, Turkey
}

\begin{abstract}
This research is the first study on wild orphan animals in Turkey. The aim of this study is to evaluate the reasons of the orphans' arrival, their health status and fate in the Afyon Kocatepe University Wildlife Rescue Rehabilitation, Training, Practice and Research Center. Data on 118 orphans accepted the center in 2017, 2018 and 2019 were evaluated. A total of 16 different species, including 12 birds and 4 mammals, were recorded. Most of the orphans $(89 \%)$ were birds and few mammals (11\%). Most of the orphans (45.8\%) were accepted to the center during the breeding seasons, especially in July. Most of the orphan birds were from the urban areas $(94.3 \%)$ while most of the orphan mammals were from the rural areas $(84.6 \%)$. The majority of orphans $(81.4 \%)$ admitted to the rehabilitation center were uninjured and healthy. The mortality rate in the rehabilitation center $(47.5 \%)$ was higher than those who were successfully released into wildlife $(40.7 \%)$, those in captivity $(5.9 \%)$ and euthanasia $(5.9 \%)$. Despite the high rate of healthy offspring, the high mortality rate indicates that the rehabilitation process is difficult and requires expertise. As a result, not all wild offspring found by humans are orphans. Leaving healthy offspring in their habitat in a controlled manner can increase their chances of survival. It has been concluded that increasing education and awareness-raising activities both in rehabilitation centers and in the community will reduce the problem of orphans in wildlife.
\end{abstract}

Keywords: Afyonkarahisar, biodiversity, conservation, rescue, Turkey, wildlife

\section{Afyon Kocatepe Üniversitesi Yaban Hayatı Kurtarma Rehabilitasyon Eğitim Uygulama ve Araştırma Merkezindeki (AKUREM) Yabani Öksüz Yavrular Üzerine Bir Retrospektif Araştırma}

ÖZ

$\mathrm{Bu}$ araştırma Türkiye'deki öksüz yaban hayvanları üzerine yapılan ilk çalışmadır. Bu çalışmanın amacı, Afyon Kocatepe Üniversitesi Yaban Hayatı Kurtarma Rehabilitasyon Eğitim Uygulama ve Araştırma Merkezi'ne getirilen yaban hayatı öksüz yavrularının geliş nedenlerini, sağlık durumlarını ve akibetlerini değerlendirmektir. Merkeze, 2017, 2018 ve 2019 ylllarında getirilen 118 öksüz yavruya ait veriler değerlendirilmiştir. Onikisi kuş ve dördü memeli olmak üzere toplamda onaltı farklı tür kayıt altına alınmıştır. Öksüz yavruların çoğunluğu kuşlardan (\%89), azınlığ ise memelilerden (\%11) oluşmuştur. Öksüz yavrular üreme sezonunda, yoğun olarak da Temmuz ayında (\%45.8) merkeze kabul edilmiştir. Öksüz kuşların büyük kısmı (\%94.3) kentsel alanlardan, öksüz memeliler ise daha çok (\%84.6) kırsal alanlardan getirilmiştir. Rehabilitasyon merkezine kabul edilen öksüz yavruların çoğunluğu (\%81.4) zarar görmemiş ve sağlıklıydı. Rehabilitasyon merkezindeki ölüm oranı (\%47.5), yaban hayatına başarıyla salınanlardan (\%40.7), esaret altında tutulanlardan (\%5.9) ve ötenazi yapilanlardan (\%5.9) daha yüksek bulunmuştur. Sağlıklı yavru oranı yüksek olmasına rağmen ölüm oranının yüksek olması rehabilitasyon sürecinin güçlügünü ve uzmanlık gerektirdiğini göstermektedir. Sonuç olarak, insanlar tarafindan bulunan her yabani yavru öksüz değildir. Sağlıklı yavruların yaşam alanlarında kontrollü bir şekilde bırakılması hayatta kalma şanslarını artırabilir. Bu konuda, hem rehabilitasyon merkezlerinde hem de toplumda eğitim ve bilinçlendirme faaliyetlerinin artırlmasının yaban hayatındaki öksüz yavru sorununu azaltacağı kanaatine varılmıştır.

Anahtar Kelimeler: Afyonkarahisar, biyoçeşitlilik, koruma, kurtarma, Türkiye, yaban hayatı

To cite this article: Kandir E.H. Gül T.C. A Retrospectuve Study on Wild Orphan Anmals in Afyon Kocatepe Unversity Wildlufe Rescue Rehabulitation, Traming, Practice and Research Center (Akurem). Kocatepe Vet J. (2020) 13(3):272-280 


\section{INTRODUCTION}

Wildlife are under threat from many different kinds of human activities not only in Turkey but also all over the World. With the industrialization and technological developments, the increase in the human population has reduced the distance between wild life and human beings and in some areas, species extinctions have started to occur due to human activities. As the urbanization of areas with wildlife habitats continues to increase, oppression are enforced on the wild animals (Schenk and Souza, 2014; Mckinney, 2002). Wild animals are harmed in nature by anthropogenic and natural causes (MolinaLo'pez et al., 2017). Nowadays, it is inevitable to take wildlife protection measures, as many species are already extinct and many are in danger of extinction. This 6th wave of extinction of life, which has previously disappeared five times, is accelerating with human influence. It is necessary to reduce the destructive pressure of humans on wildlife (Ceballos et all, 2010).

Wildlife Rehabilitation is described as the treatment and impermanent care of injured, diseased and displaced or orphaned wild animals, and ultimately they can be returned to their natural habitat (Miller, 2012). Treating and rehabilitating animals that are damaged and releasing them to nature is one of the methods of wildlife protection. Rehabilitated wild animals can get a chance to live in nature again (Grogan and Kelly, 2013). "Orphaned" means that chicks, fledgling or young animals, supposedly abandoned by their parents or fallen from their nest or brought by humans on the grounds that they are alone in nature. Especially juvenil animals are seriously admission to wildlife rescue centers (Mullineaux, 2014). Since every wild animal babies need unique care and diets, wild orphan animal raising and releasing is very difficult in the rehabilitation center. Wildlife rehabilitation specialists and veterinarians who care for wild babies must know how to care for wild animals. On the other hand, while people teach orphaned wild animals how to survive in wild, they are not as competent as wild parents (Moore and Joosten, 1997, Ruth, 2012, Miller, 2012). Wild babies raised by humans may have problems in detecting dangerous situations to be avoided, getting to know all the nutrients, caring for babies, and communicating with each other in the same kinds. Many wild animals offspring are unnecessarily rehabilitated since biological parents are more succesfull than even well trained rehabilitators (Robertson and Harris 1995). Many baby animals are kidnapped by well-intentioned people. People want to save the offspring when they see alone and think they are abandoned. Unfortunately the fact is that, most of the baby animals encountered in the wild are not orphaned or abandoned and they don't need help (Ruth, 2012, Miller, 2012). First of all we accept this situation and then decide if wild animal need help or not. If the mother is known to be dead, if the baby has obvious injuries or look sick, if the baby is crying and appears to be poorly fed and dehydrated, then wild baby animals need help and should be rescued. In some cases, the baby needs only little help. Maybe it can be dropped into the nest where it fell from or abondoned. Although they are not injured, there are three obstacles to the offspring being considered orphans by being taken away from nature. It is important that whether these orphans will survive in rehabilitation centers, will orphans gain sufficient skills to survive, will orphans find a living space in nature without harming others in the environment (Wimberger and Downs, 2010). Wild animals take care of their offspring in a variety of ways, that may look like unusual behavior to us but it is actually just a normal part of the animal's strategy for survival in nature. Unfortunately, human raising strategies remain insufficient in this regard. (Tseng, 2002).

Afyonkarahisar is a rich province about biodiversity, located on bird migration routes due to its large number of wetlands, with habitats suitable for different animal species as it is at the transition area between the Aegean and Central Anatolia regions. For this reason, Afyon Kocatepe University Wildlife Rescue Rehabilitation Education Practice and Research Center (AKUREM) was started their activity in 2017. AKUREM is one of the a few rehabilitation center, assigned the task of rescuing and rehabilitating wild animals in Turkey.

Apart from Afyonkarahisar, AKUREM also provides services to wild animals brought from Eskişehir, Kütahya, Uşak and Denizli provinces within the scope of the protocol signed with the V. Regional Directorate of Nature Conservation and National Parks (DKMP). Wild animals, which are damaged in nature, are picked up by the Nature Conservation and National Parks Authorities and sent to the center upon the notification of citizens and mostly sensitive citizens. Among the many activities of the AKUREM, the care and feeding of orphaned offspring occupies an important place. When the breeding season starts in spring, many wild offspring are brought to AKUREM that they are found sometimes injured, sometimes sick but mostly healty on the ground. In this study probable reasons and therefore the fate patterns of wild orphan animals are investigated in a wildlife rehabilitation center in Turkey.

\section{MATERIALS and METHODS}

Between the period from 2017 to 2019 a total of 640 injured wild animals were brought to AKUREM in which 118 of them $(18,4 \%)$ was orphan animals. A retrospective study was conducted based on the data of 118 applications of wild orphan animals to evaluate their fate at the AKUREM. The rehabilitation center is operated under the direction of the Afyon Kocatepe University, who stipulates the management 
protocols and Ethical Principles according to the DKMP legislation.

Species were grouped into the following broader taxonomic categories for statistical analyses purpose. These groups were clasified as 13 mammals (including Artiodactyla-Red Deer, Carnivora-Red Fox, Equidea-Feral Horse, Rodentia-Red Squirrel) and 105 aves (including Accipitriformes- Common Kestrel, Long- legged buzzard, Eurasian hobby, Imperial Eagle, Apodiformes- Common Swift; Ciconiformes - Stork; Columbiformes- Pigeon; Cuculiformes- Common Cuckoo; PasseriformesEurasian Magpie and Sparrow; Piciformes- Syrian Woodpecker; Strigiformes- Long Eared Owl).

Information that was collected on admission of orphaned animals included rescue center number, date of admission, location found, reason for presentation and fate status. Relevant data was organised into a computerised database (Microsoft Office Professional Plus 2010, Microsoft Corporation, Redmond, Washington, USA). Microsoft Excel was used to calculate the summary statistics (totals, means and proportions), and to create graphical outputs.

\section{RESULTS}

The evaluation process was made on 118 admission (18.4\% of all the admissions) reports (Figure 1).

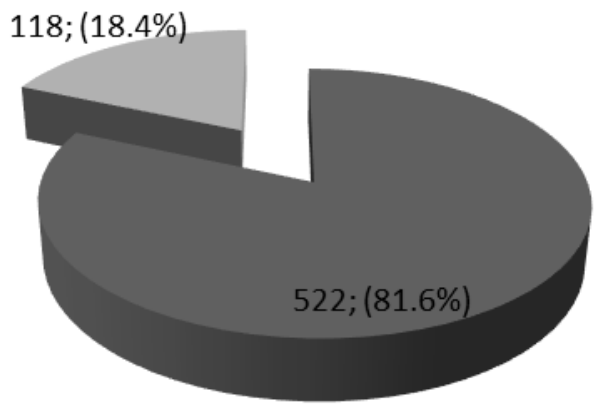

- OTHER CASES

ORPHAN ANIMALS

Figure 1. Percentages of total wild animals accepted to AKUREM from 2017 to 2019

Birds admission (89\%) were more than the mamalian admission (11\%) in the rehabilitation center (Figure 2).

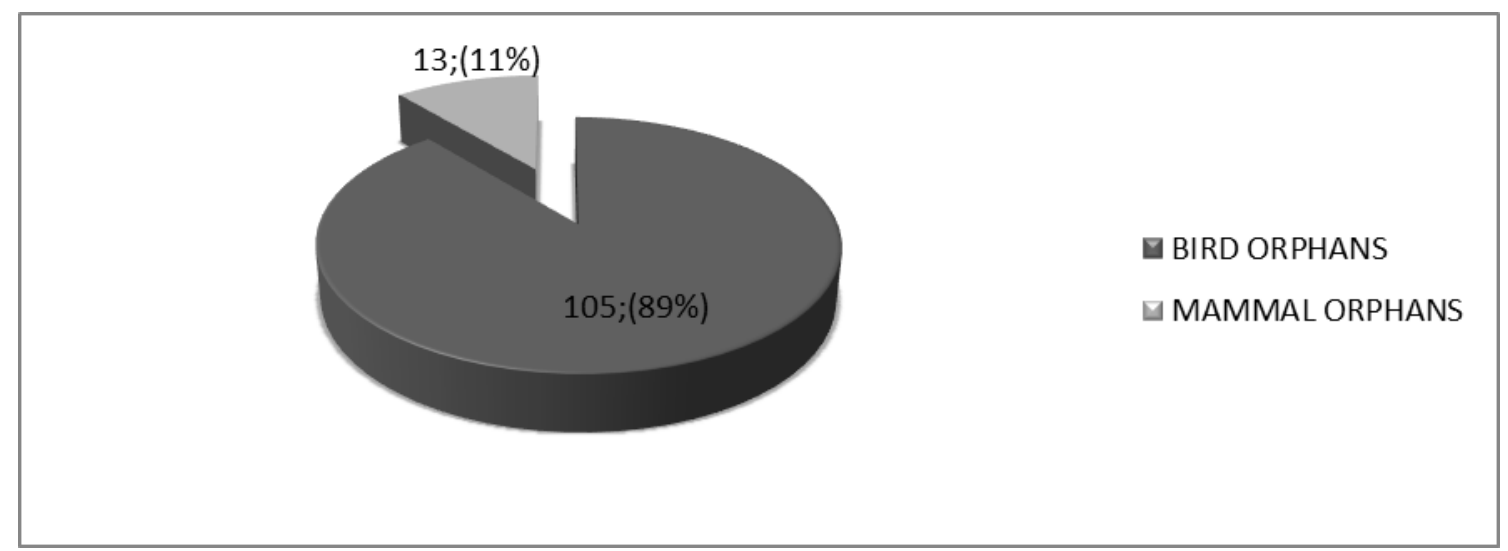

Figure 2. Percentages of orphan wild animals accepted to AKUREM from 2017 to 2019

The group under investigation was covered 16 different species. Four of these species were mammals and contained 13 animals under four orders namely Artiodactyla, Carnivora, Equidea and Rodentia. The remaining other 12 species were birds and contained 105 animals under 8 orders namely
Accipitriformes, Apodiformes, Ciconiformes, Columbiformes, Cuculiformes, Passeriformes, Piciformes, Strigiformes. The distribution of the animals according to species and oders are given in Table 1. Only one animals, Imperial eagle (Aquila heliaca) was Vulnerable (VU) statues and the others were considered as Least Concerned (LC) categories 
and by the IUCN (International Union for Conservation of Nature and Natural Resources) red list. Among the orphaned mammals accepted to the rehabilitation center, the highest rate were belongs to red deer $(53.8 \%)$, followed by red fox $(23.1 \%)$, red squirrel $(15.4 \%)$ and feral foal $(7.7 \%)$ respectively.
Among the orphaned birds, the most frequently brought to the center, were common kestrel (Falco tinnunculus) $(24.8 \%)$, common swift (Apus apus) $(21.9 \%)$, pigeon (Columba livia) $(19 \%)$ and eurasian magpie (Pica pica) (13.3\%) respectively.

Table 1: Species in this research

MAMMALS

\begin{tabular}{llc}
\hline Artiodactyla & $\mathrm{N}$ & $\%$ \\
\hline Red Deer (Cervus elaphus) & 7 & 53.8 \\
Carnivora & 3 & 23.1 \\
Red Fox (Vulpes vulpes) & & 7.7 \\
Equidea & 1 & 15.4 \\
Feral Horse (Equus caballus) & & $\mathbf{1 0 0}$ \\
Rodentia & 2 & $\mathbf{1 3}$ \\
Red Squirrel (Sciurus vulgaris) & &
\end{tabular}

\section{BIRDS}

\begin{tabular}{|c|c|c|}
\hline Accipitriformes & $\mathrm{N}$ & $\%$ \\
\hline Common Kestrel (Falco tinnunculus) & 26 & 24.8 \\
\hline Long-legged buzzard (Buteo rufinus) & 2 & 1.9 \\
\hline Eurasian hobby (Falco subbuteo) & 1 & 0.95 \\
\hline Imperial Eagle (Aquila heliaca) & 1 & 0.95 \\
\hline \multicolumn{3}{|l|}{ Apodiformes } \\
\hline Common Swift (Apus apus) & 23 & 21.9 \\
\hline \multicolumn{3}{|l|}{ Ciconiformes } \\
\hline Stork (Ciconia ciconia) & 5 & 4.8 \\
\hline \multicolumn{3}{|l|}{ Columbiformes } \\
\hline Pigeon (Columba livia) & 20 & 19.0 \\
\hline \multicolumn{3}{|l|}{ Cuculiformes } \\
\hline Common Cuckoo (Cuculus canorus) & 1 & 0.95 \\
\hline \multicolumn{3}{|l|}{ Passeriformes } \\
\hline Eurasian Magpie (Pica pica) & 14 & 13.3 \\
\hline Sparrow (Passer domesticus) & 3 & 2.9 \\
\hline \multicolumn{3}{|l|}{ Piciformes } \\
\hline Syrian Woodpecker (Dendrocopos syriacus) & 1 & 0.95 \\
\hline \multicolumn{3}{|l|}{ Strigiformes } \\
\hline Long Eared Owl (Asio otus) & 8 & 7.6 \\
\hline Total & 105 & 100 \\
\hline
\end{tabular}


The distribution of orphaned mammals and birds admitted by the center by years and months are given in Table 2. In this study, the orphan rates were increased by the years (2017, 2018, 2019); 25, 36, 57 respectively. The breeding season (spring and summer months), especially in July, more orphan were admitted to center $(45.8 \%)$. The proportion of orphaned accepted to the center regardless to the species in March, April, May, June, August, September and October were 0.9, 2.5, 23.7, 18.6, 5.9, 0.9 and $1.7 \%$ respectively. In autumn season, only juvenile pigeon were admitted to the center.

Table 2: Distribution of admitted orphans by season and months

\begin{tabular}{|c|c|c|c|c|c|c|c|c|c|c|}
\hline \multirow{2}{*}{ Years } & \multirow{2}{*}{ Orphan } & \multicolumn{9}{|c|}{ MONTHS* } \\
\hline & & 3. & 4. & 5. & 6. & 7. & 8. & 9. & 10. & TOTAL \\
\hline \multirow{3}{*}{2017} & Mammals & 0 & 0 & 2 & 1 & 1 & 0 & 0 & 0 & 4 \\
\hline & Birds & 0 & 2 & 2 & 2 & 11 & 4 & 0 & 0 & 21 \\
\hline & & & & & & & & & TOTAL & 25 \\
\hline \multirow{3}{*}{2018} & Mammals & 0 & 0 & 3 & 1 & 0 & 0 & 0 & 0 & 4 \\
\hline & Birds & 0 & 0 & 4 & 11 & 14 & 2 & 1 & 0 & 32 \\
\hline & & & & & & & & & TOTAL & 36 \\
\hline \multirow{3}{*}{2019} & Mammals & 1 & 0 & 0 & 3 & 1 & 0 & 0 & 0 & 4 \\
\hline & Birds & 0 & 1 & 17 & 4 & 27 & 1 & 0 & 2 & 53 \\
\hline & & & & & & & & & TOTAL & 57 \\
\hline TOTAL & & 1 & 3 & 28 & 22 & 54 & 7 & 1 & 2 & 118 \\
\hline$\%$ & & 0.9 & 2.5 & 23.7 & 18.6 & 45.8 & 5.9 & 0.9 & 1.7 & 100 \\
\hline Seasons & & \multicolumn{3}{|c|}{ Spring } & \multicolumn{3}{|c|}{ Summer } & \multicolumn{3}{|c|}{ Autumn } \\
\hline
\end{tabular}

*3. March, 4. April, 5. May, 6. June, 7. July, 8. August, 9. September, 10. October

The health status of orphaned animals brought to the center is shown in Figure 3 and $81.4 \%$ of orphans brought to the center were healthy while $18.6 \%$ of the orphans were found to be sick, frail or injured.

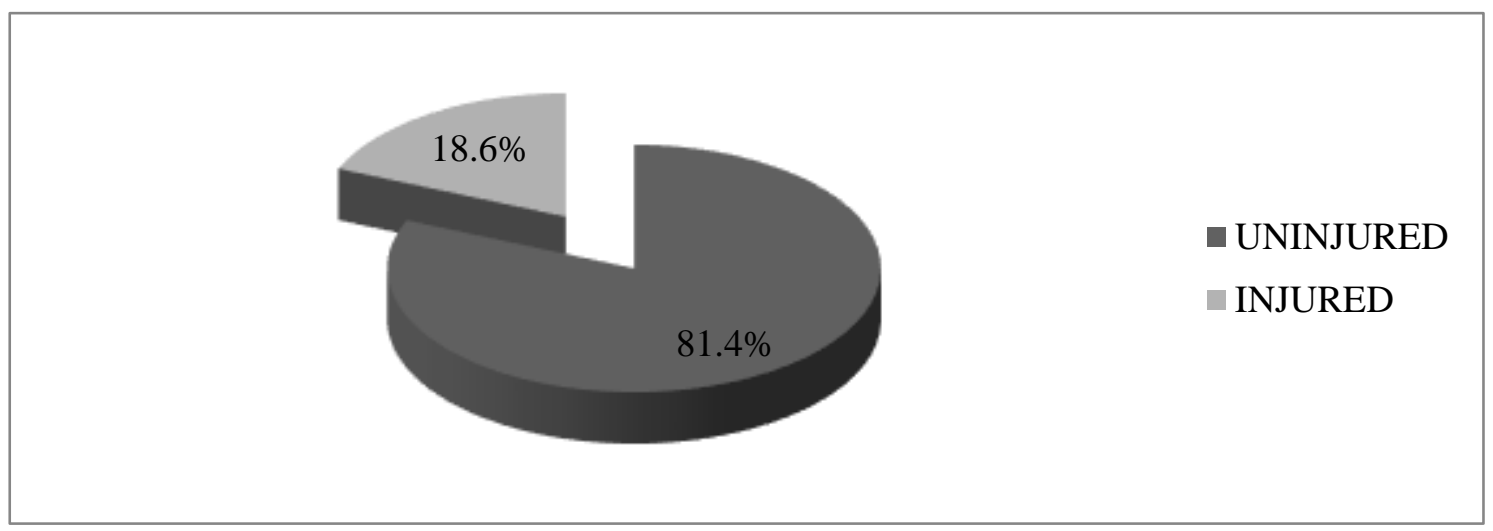

Figure 3. Health status of orphan animals

Information about the areas where the orphans found and brought to AKUREM is shown in Table 3. As it is easily seen from the Table 3, most of the orphans $(85.6 \%)$ came from the urban areas, while 14.4\% came from rural areas. $94.3 \%$ orphans from urban areas were belongs to avian species while $15,4 \%$ were belongs to mammals. Opposite to this, $84.6 \%$ of the orphans from rural areas were belongs to mammals while only $5.7 \%$ were belongs to avian species. 
Table 3: The areas where the orphans found

\begin{tabular}{llllll}
\multicolumn{2}{c}{ URBAN AREA } & \multicolumn{2}{l}{ RURAL AREA } & \multicolumn{2}{l}{ TOTAL } \\
\hline $\mathrm{n}$ & $\%$ & $\mathrm{n}$ & $\%$ & $\mathrm{n}$ & $\%$ \\
2 & 15.4 & 11 & 84.6 & 13 & $\mathbf{1 4 . 4}$ \\
99 & 94.3 & 6 & 5.7 & 105 & $\mathbf{8 5 . 6}$
\end{tabular}

The reasons for orphans' acceptance to the center are reported in Table 4 . The causes can be classified as uninjured orphan 81.4\%, animal attacked 2.5\%, entangled or adhesive $4.2 \%$ and injured $11.9 \%$ were determined. When an overall assessment of the causes of orphans admitted to the center was made, the rate of uninjured orphans was found at the highest $(81.4 \%)$. The rate of uninjured orphans were found to be high in both birds $(81.9 \%)$ and mammals $(53.8 \%)$

Table 4. Descriptions of the reasons of the orphans to be accepted to the rehabilitation centre

\begin{tabular}{|c|c|c|c|c|c|c|c|}
\hline \multirow{3}{*}{ Causes } & \multirow{3}{*}{ Description } & \multicolumn{4}{|c|}{ Case number } & \multicolumn{2}{|c|}{ Total } \\
\hline & & \multicolumn{2}{|c|}{ Birds } & \multicolumn{2}{|c|}{ Mammals } & \multirow[b]{2}{*}{$\mathrm{n}$} & \multirow[b]{2}{*}{$\%$} \\
\hline & & $\mathrm{n}$ & $\%$ & $\mathrm{n}$ & $\%$ & & \\
\hline Uninjured & Orphan with no injuries & 89 & 81.9 & 7 & 53.8 & 96 & 81.4 \\
\hline Animal attack & $\begin{array}{l}\text { Attacked by dog, cat or non-domestic } \\
\text { animals }\end{array}$ & 1 & 0.9 & 2 & 15.4 & 3 & 2.5 \\
\hline $\begin{array}{l}\text { Entangled or } \\
\text { adhesive }\end{array}$ & $\begin{array}{l}\text { Entangled in string, fishing line or } \\
\text { smeared with adhesive }\end{array}$ & 5 & 4.8 & 0 & 0 & 5 & 4.2 \\
\hline Injured & $\begin{array}{l}\text { Broken bones, wounds, paralysed, blind } \\
\text { or concussed }\end{array}$ & 10 & 9.5 & 4 & 30.8 & 14 & 11.9 \\
\hline TOTAL & & 105 & 100 & 13 & 100 & 118 & 100 \\
\hline
\end{tabular}

Descriptions of condition and fate patterns of orphaned animals admitted to the rehabilitation centre is shown in Table 5. After rescue, release to the wild life, captivity, euthanasia and mortality the rate were 42.9, 0.9, 6.7 and $49.5 \%$ for birds while
$23.1,46.2,0,30.7 \%$ for mammals respectively. When taking the total numbers into account for mixed species the rates were found to be 40.7, 5.9, 5.9, $47.5 \%$.

Table 5. Definitions of the status and destiny patterns of orphans admitted to the rehabilitation center

\begin{tabular}{|c|c|c|c|c|c|c|c|c|}
\hline \multirow{3}{*}{ Fate patterns } & \multirow{3}{*}{ Description } & & \multicolumn{4}{|c|}{ Case number } & \multicolumn{2}{|c|}{ TOTAL } \\
\hline & & & \multicolumn{2}{|c|}{ Birds } & \multicolumn{2}{|c|}{ Mammals } & \multirow[b]{2}{*}{$\mathrm{n}$} & \multirow[b]{2}{*}{$\%$} \\
\hline & & & $\mathrm{n}$ & $\%$ & $\mathrm{n}$ & $\%$ & & \\
\hline Release to wild & $\begin{array}{l}\text { Releasable orphan, } \\
\text { successfully survive in the wild }\end{array}$ & may & 45 & 42.9 & 3 & 23.1 & 48 & 40.7 \\
\hline Captivity & $\begin{array}{l}\text { Non-releasable orphan, } \\
\text { survivability in the wild }\end{array}$ & poor & 1 & 0.9 & 6 & 46.2 & 7 & 5.9 \\
\hline Euthanasia & $\begin{array}{l}\text { Humanely assisted death, } \\
\text { worst prognosis }\end{array}$ & with & 7 & 6.7 & 0 & 0 & 7 & 5.9 \\
\hline Died & Unassisted natural death & & 52 & 49.5 & 4 & 30.7 & 56 & 47.5 \\
\hline TOTAL & & & 105 & 100 & 13 & 100 & 118 & 100 \\
\hline
\end{tabular}




\section{DISCUSSION}

In this study which as explained in the materials and methods, the ratio of orphans was $18.4 \%$ of all the wild injured animals (640) brought to the Akurem. This ratio of orphans brought to any rehabilitation centre was more or less similar to that of the studies made in Australia (24.65\%-Taylor-Brown A, et al., 2019), in South Africa (43\% -Wimberger\&Downs, 2010) and in Alabama USA (74\%-Williamson\& Lepczyk, 2017). As can be understood from the ratios, orphaned animals have occupied a significant position at the some different rehabilitation centers.

It was observed that the bigger proportion of the orphans admitted to the AKUREM was birds (89\%) and the rest was mammals $(11 \%)$. It was reported by Smith (2016) that the most of the orphans come to the rehabilitation center in the spring was birds rather than mammals. Similarly, statistics from the data for the year 2000, indicated that approximately 67\% of casualties were birds, and 32\% mammals (Kirkwood, 2003).

The reason for this seems that the habitats between human and birds are much closer compare to mammals and therefore birds seems to be much vulnerable than mammals. One can assume that the spring was the time of the year that the breeding season for birds started and it is most likely that the fledgling may fallen from their nests during spring (Smith, 2016).

On the contrary, more mammals (56.6\%) were brought to wildlife rescue centers rather than birds in Australia (Taylor-Brown et al. 2019). However, in the BWRC (British Wildlife Rehabilitation Council) analysis showed that $50 \%$ of birds and $54 \%$ of mammals admissions were of offspring animals (Kirkwood 2003) in the UK. It is thought that wildlife rescue centers' habitat and biodiversity situation affects this ratio between birds and mammals. Among the orphaned mammals the highest rate belongs to red deer fawn with 53.8\% Table 1. Red deer fawn can walk shortly after birth, and they won't begin to follow their mother until about one month of age. For this reason, their mother keeps them in a suitable place, for example in the bush, and goes to feed and returns soon. Spotted coats of the fawns serve as camouflage having no smell to help to avoid to be found by predators.

In this study, the orphan number was increased by the years, and the number of orphans adopted in 2019 was the highest (Table 2). This can be explained by the fact that the effectiveness of the operation of the center has increased over the years. On the other hand, this finding may also indicate that the social awareness to wild life is developing among the people by the time. It's common for humans to encounter baby birds and mammals during the birth or incubation season (spring and summer). In our study, the offspring were mostly admitted to center in July
(45.8\%) that was similarly reported by Wimberger and Down (2010). They reported that incubation of birds that hatch several times, such as pigeons, can also be admitted to the center in autumn in South Africa. This finding also supported by Kelly and Bland (2006). They reported that admissions for European sparrowhawks (Accipiter nisus) species were mostly seasonal, with most birds being admitted between July and September.

Many wild orphan animals $(85.6 \%)$ brought to the AKUREM were from the urban areas while $14.4 \%$ were from rural. $94.3 \%$ of the orphans in urban areas were belongs to birds while only $15.4 \%$ were mammals. This can be explained by the fact that birds live closer to humans in urban areas (Table 3). Among the birds, common kestrel (24.8\%), common swifts $(21.9 \%)$ and pigeons $(19.0 \%)$ were admitted distinctively more than the other species (Table 1). Those birds living in close association with humans were the most frequently admitted to rehabilitation centres. Some bird species such as pigeons live close to humans as they can meet a significant portion of their food requirements in urban areas (Marchesini, 2016). The reason why orphan birds are higher in urban areas may be due to the possibility of nesting in roof and roof eaves of the buildings. Wild birds can build their nests on trees, shrubs, under rocks and tree stumps, and in chimneys. As stated by Soulsbury and White (2015) urban wildlife has both positive and negative interactions with people. Since birds live close to humans, their offspring are easily found and easily collected, while mammals often avoid humans and tend to be encountered only when they clash with humans (Wimberger and Down, 2010).

In this study, $81.4 \%$ of orphans admitted to the center were identified as uninjured juvenils and most of them $(81.9 \%)$ was orphan birds. Baby birds can spend days to weeks in the nest and they are fed by their parents during their early period of life. If the baby birds that fallen from their nest was healthy, they must be placed back in their nests by the rescuers. At the early ages the healthy baby birds may leave the nest and hop along the neighboring branches for gaining strength or flying exercise may fallen ground. In that case, people with not enough knowledge about wildlife find those animals, they think that those animals are orphan and unnecessarily take such animals to rehabilitation center. (Williamson\&Lepczyk 2017). Normally those animals should be placed back to their parents care in their nests. If the fledging is looks healty should be left at a point where cats, dogs and other creatures cannot reach without being removed from their area (Miller, 2012).

After rescue and rehabilitation process, orphaned animal releasing success was $40.7 \%$ (Table 5). This finding was supported Grogan and Kelly (2013). It was reported by RSPCA's (Royal Society for the Prevention of Cruelty to Animals) wildlife centres as the typical of other wildlife centres in the UK, around 
40 per cent of casualties are released. Releasing success was higher $(42.9 \%)$ in birds than the mammals $(23.1 \%)$. This finding is thought to be due to the arrival of many healthy uninjured juvenil birds. Kelly et all. (2011) have found the release rate of 31\% in orphaned wood pigeons (Columba palumbus) and they have found the euthanased rate of $37 \%$, the died rate was $30 \%$. On the other hand our euthanased rate was only $6.7 \%$ and mortality rate was $49.5 \%$ in birds. The reason was that in some cases we hoped that they would get better rather than euthanased, but it didn't happen. Unfortunately, the death rate $(47.5 \%)$ was more than our releasing rate $(40.7 \%)$ for all the orphans.

The rate of captivity was found to be very high $(46.2 \%)$ in unhealthy orphan mammals (Table 5). For some orphaned wild animals, life in captivity is safer. The prognosis for rescued orphans in captivity is not always positive. They needed specialized care with special care facilities, time and resource. Furthermore, they are especially susceptible to disease and other captivity related problems (imprinting). Hovewer, fledglings have a much better chance of survival in the wild than in captivity (Smith, 2016). We can say that the survival skills of orphaned birds thrown out by their families from their nests are poor, even if they seem physically healthy. This may be the reason for the mortality rate which was quite high. On the other hand, this high mortality rate also may be due to the fact that our center has been in operation recently and therefore our facilities are not sufficient. Insufficiency of wildlife veterinarians and rehabilitators and their lack of education in Turkey have previously been reported by Kandir\&Aslan (2017). It is obvious that the high standard facilities, care programs, housing systems, hygiene, handling, nutrition and treatment practices are important factors for rehabilitation success (Dubois and Fraser, 2003).

Captivity rate for unhealthy orphan mammals was found very high $(46.2 \%)$. For some orphaned wild animals, life in captivity is safer then release to nature. Because of some young animals raised by human, think themselves are human and they may develop a different instict from others. Animals that develop instincts in this way will not want to be with other members of their own species and will not be able to properly interact with them (Ruth, 2012). Regarding the fate of orphan mammals, 5 red deer fawn (Cervus elaphus) were sent to a semi-natural area belonging to DKMP after weaning (kept in captivity) and one feral horse (Equus caballus) yearling continues to be kept in captivity in the AKUREM. Of the birds, only one Imperial Eagle (Aquila heliaca) could not return to nature due to wings problem and remained in the center for student educational purposes.

\section{CONCLUSIONS}

This research is important as it is the first study in Turkey for orphaned wild animals to examine the acceptance reasons and fate patterns in the wildlife rehabilitation center. Every breeding season, a large number of wild orphan animals are taken to rehabilitation centres for treatment, care, raise and release. Therefore, the analysis of admission records of wild orphan animals to the rehabilitation center and the resulting actions can provide important information about wildlife rescue. Three important conclusions were reached in this research;

1. Social education and awareness activities on this subject will reduce the problem associated with orphan animals in the wildlife.

2. With the technical knowledge obtained from the researches on wildlife, the attractiveness of the research making will increase and as a result, the success of the rehabilitation centers will increase.

3. Increasing the number of such studies will be an opportunity for wildlife rehabilitation centers to measure their success and reach higher levels. In this context, it can be concluded that cooperation between countries is important in the partnership of states, universities and NGOs.

Conflict of Interest: The authors declare that they have no conflict of interest.

\section{REFERENCES}

Ceballos, G., García, A., Ehrlich, P.R. (2010). The sixth extinction crisis: loss of animal populations and species. Journal of Cosmology, 2010, Vol 8, 1821-1831.

Dubois, S., Fraser, D. (2003). Defining and measuring success in wildlife rehabilitation, Wildlife Rehabilitation, 21: 123132.

Grogan, A., Kelly, A. (2013). A review of RSPCA research into wildlife rehabilitation, Veterinary Record, 1-4, DOI: 10.1136/vr.101139.

Kandir, E.H., Aslan A. (2017). An investigation on releasing treated wild animals into the nature in Turkey, Applied Ecology and Environmental Research, 15(4):1757-1763. DOI: 10.15666/aeer/1504_17571763.

Kelly, A., Bland, M. (2006). Admissions, diagnoses, and outcomes for eurasian sparrowhawks (Accipiter nisus) brought to a wildlife rehabilitation center in England. Journal of Raptor Research 40, 231-235.

Kelly, A., Halstead, C., Hunter, D., et al. (2011). Factors affecting the likelihood of release of injured and orphaned woodpigeons (Columba palumbus). Animal Welfare 20, 523-534.

Kirkwood, J.K. (2003). Introduction: wildlife casualties and the veterinary surgeon. In: BSAVA Manual of Wildlife Casualties. Eds E. Mullineaux, D. Best and J. E. Cooper. BSAVA Publications, Gloucester, MA, USA. pp 1-5. 
Marchesini, R. (2016). Animals of the city. Angelaki: Journal of the Theoretical Humanities, 21, pp. 79-91.

McKinney, M.L. (2002). Urbanization, Biodiversity, and Conservation: The impacts of urbanization on native species are poorly studied, but educating a highly urbanized human population about these impacts can greatly improve species conservation in all ecosystems. BioScience. 52(10):883-890.

Miller, E. A. (2012). Minimum Standards for Wildlife Rehabilitation. 4th edn. National Wildlife Rehabilitators Association and International Wildlife Rehabilitation Council, St. Cloud, MN, USA.

Molina-Lo'pez RA, Mañosa S, Torres-Riera A, Pomarol M, Darwich L (2017). Morbidity, outcomes and cost-benefit analysis of wildlife rehabilitation in Catalonia (Spain), PLoS One, DOI: 10.1371/journal.pone.0181331.

Moore, A.T., Joosten, S. (1997). Principles of Wildlife Rehabilitation-The Essential Guide for Novice and Experienced Rehabilitators. St. Cloud, MN: National Wildlife Rehabilitators Association.

Mullineaux, E (2014). Veterinary treatment and rehabilitation of indigenous wildlife, Journal of Small Animal Practice, Vol 55:293-300

Robertson C and Harris S (1995). The Behaviour After Release of Captive-reared Fox Cubs. Animal Welfare, 4(4): 295306 (12).

Ruth, I (2012). Wildlife Care Basics for Veterinary Hospitals Before the Rehabilitator Arrives, https://www.hsvma.org/assets/pdfs/hsvma_wildlife_car e_handbook.pdf.

Schenk AN, Souza MJ (2014). Major anthropogenic causes for and outcomes of wild animal presentation to a wildlife clinic in East Tennessee, USA, 2000-2011. PLoS One; 9(3):1-3, e93517, DOI: 10.1371/journal.pone.0093517

Smith S (2016). Principles of capture, handling and transportation. In: BSAVA Manual of Wildlife Casualties. 2rd ed, British Small Animal Veterinary Association, England: pp 17-26.

Soulsbury CD, White CLP (2015). Human-wildlife interactions in urban areas: a review of conflicts, benefits and opportunities, Wildlife Research, 42(7):541-553.

Taylor-Brown A, Booth R, Gillett A, Mealy E, Ogbourne SM, Polkinghorne A, Conroy GC (2019). The impact of human activities on Australian wildlife, Research Article, PLoS One, DOI: 10.1371/journal.pone.0206958.

Tseng FS (2002). Neonatal Wildlife Care, [accessed 05 January 2020]

https://michvma.org/resources/Documents/MVC/201 7\%20Proceedings/tseng $\% 2002 . p d f$

Williamson S and Lepczyk C (2017). Mortality and injury rates of wildlife reported by rehabilitators across Alabama, Auburn University Journal of Undergraduate Scholarship, $1-6$.

Wimberger K and Downs CT (2010). Annual intake trends of a large urban animal rehabilitation centre in South Africa: a case study. Animal Welfare 19, 501-513. 